\title{
Low reproductive performance and high sow mortality in a pig breeding herd: a case study
}

Rueda López, MA

Kiernan Milling, Veterinary Clinic, Granard, Co. Longford, Ireland

\section{ABSTRACT}

Sow performance is a key component of the productivity of commercial pig farms. Reproductive failure in the sow is common in pig production. For every 100 sows served, 89 should farrow. In absence of specific diseases such as porcine parvovirus, pseudo-rabies, swine fever, leptospirosis and brucellosis, management failures are the most important causes of loss. A syndrome associated with reproductive inefficiency, and post-service vaginal discharge and high sow mortality in a commercial pig farm is described. Pregnancy failures exceeded $20 \%$ and sow mortality exceeded $12 \%$ for two consecutive years. The abnormal post-service vaginal discharge rate was $1.7 \%$ during the period of investigation.

An investigation involving an analysis of farm records, a review of breeding management practices, clinical examinations, laboratory analysis and examination of urogenital organs was conducted.

The main contributing factors found were a sub-optimal gilt breeding management, an inadequate culling policy in combination with a sub-optimal culling rate and the presence of cystitis in more than $1 \%$ of the urogenital organs examined. The high sow mortality rate was related to an aged breeding herd.

A control programme was recommended based on management changes involving oestrus detection, movement of gilts post-service, hygiene in the service area, boar exposure post-service and urinary acidification. This programme failed to increase the farrowing rate due to incomplete implementation of the recommendations made. The farrowing rate increased to $86.5 \%$ subsequent to a farm manager change in January 2005, which resulted in complete implementation of the control programme.

KEYWORDS: cystitis, farrowing rate, sow, vulval discharge

\section{CORRESPONDING AUTHOR:}

Miguel A Rueda López

Kiernan Milling, Veterinary Clinic,

Granard, Co. Longford, Ireland.

E-mail: miguel@kiernanmilling.ie

Tel: 0876888813

\section{INTRODUCTION}

The farrowing rate, described as the percentage of females served that farrowed related to first mating, decreased from an average of $86 \%$ in 2001 to $77 \%$ during the years 2002 and 2003 on a 620-sow farrow-to-finish unit. Alexander and Muirhead (1997) suggested a target farrowing rate of $89 \%$. The analysis of reproductive failures indicated that the reproductive losses during pregnancy were mainly due to high returns to oestrus and a high rate of non-pregnancy in sows. An investigation took place involving analysis of farm records, clinical examination, laboratory analysis and examination of urogenital organs. The main contributing factors to the reproductive problem in the herd were found to be sub-optimal gilt breeding management, an inadequate culling policy and the presence of cystitis in sows.

\section{CASE HISTORY}

The herd was an integrated 620-sow unit producing pigs for slaughter. Sows were accommodated in three dry
Irish Veterinary Journal Volume 61 Number 12 818-826, 2008 sow houses. The main dry sow house was a fully slatted, fan-ventilated house with 345 stalls with a service area containing 68 sow stalls. There were five farrowing rooms fully slatted with automatically controlled fan ventilation, each with 28 farrowing crates. The vaccination programme operated is shown in Table $\mathbf{1 .}$

Typically, sows were weaned on Thursdays and oestrus detection was

Table 1: Vaccination programme (1999-2006)

\begin{tabular}{|l|l|l|l|}
\hline & Parvovirus/Erysipelas & E. colf & Aujeszky's $^{3}$ \\
\hline Gilts & $\begin{array}{l}2 \mathrm{ml} \text { at selection } \\
2 \mathrm{ml}, 3 \text { weeks later }\end{array}$ & $\begin{array}{l}2 \mathrm{ml} \text { at } 6 \text { and } \\
3 \text { weeks pre- } \\
\text { farrowing }\end{array}$ & $2 \mathrm{ml}$ at selection \\
\hline Sows & $\begin{array}{l}2 \mathrm{ml}, 7 \text { days post- } \\
\text { farrowing }\end{array}$ & $2 \mathrm{ml}$ at weaning & $2 \mathrm{ml}$ every six months \\
\hline Boars & $2 \mathrm{ml}$ every 6 months & - & $2 \mathrm{ml}$ every six months \\
\hline
\end{tabular}

Parvoruvax ${ }^{T M}$. Merial Animal Health Ltd., Essex, UK Neocolipor ${ }^{T M}$, Merial Animal Health Ltd.

Porcilis Aujeszky`s. Intervet Ireland, Ireland. Discontinued in 2004. 
Table 2: Timing of service relative to detected onset of oestrus

\begin{tabular}{|l|l|l|l|l|}
\hline & \multicolumn{4}{|l}{ Time of service: Day post-weaning } \\
\hline First detected oestrus & $\begin{array}{l}\text { Day 4 } \\
\text { Monday }\end{array}$ & $\begin{array}{l}\text { Day 5 } \\
\text { Tuesday }\end{array}$ & $\begin{array}{l}\text { Day 6 } \\
\text { Wednesday }\end{array}$ & $\begin{array}{l}\text { Day 7 } \\
\text { Thursday }\end{array}$ \\
\hline Monday AM & PM & AM & & \\
\hline Tuesday AM & & AM & AM & \\
\hline Wednesday AM & & & AM & AM \\
\hline
\end{tabular}

conducted in the presence of a boar once a day from Monday vto Wednesday. Sows were served in the service area in the presence of a boar. Ninty-eight per cent of services were by artificial insemination ( $\mathrm{Al})$. The timing of services in relation to first detection of onset of oestrus is outlined in Table 2.

Semen doses were delivered three days a week and some repeat sows were served by boars. Sows were moved immediately after second service to dry sow accommodation. They were pregnancy tested at 28 days after service and transferred to the farrowing rooms on day 110 of pregnancy. The lactating feed curve is outlined in Table 3. Additional water was available from nipple

\section{Table 3: Lactating feed curve}

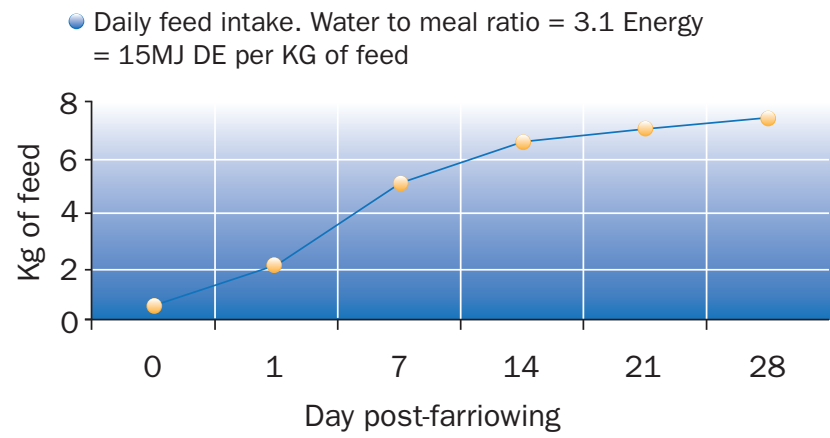

drinkers. The average lactation length was 26 days. Replacement gilts were home bred. During 2003, an average of five gilts were served per week. Before September 2003, gilts were selected at six months of age and raised up to $115 \mathrm{~kg}$ bodyweight in finishing pens, then moved to a gilt pool shed accommodating 60 gilts in three pens, and a boar in an adjoining pen. The stocking density was $2.7 \mathrm{~m}^{2}$ per gilt. Gilts were offered a gilt rearing ration ad libitum until served.

In September 2003, due to a continuous fertility problem

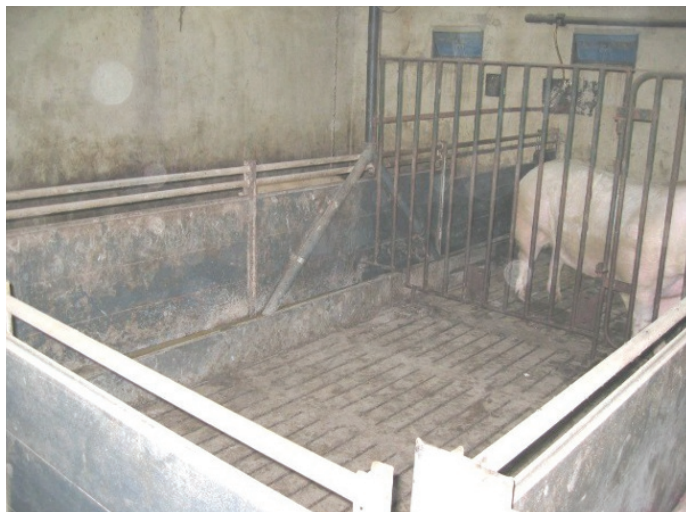

Figure 1:

Service pen used in the unit after September 2003. in gilts, the farm manager established the replacement gilts in finishing pens, in three areas:

1. A holding pool with selected gilts $(95-120 \mathrm{~kg})$, offering a finisher diet ad libitum;

2. A service pool (120-150 kg), offering a lactating sow diet ad libitum. It accommodated 49 gilts in seven pens. The stocking density was $2.7 \mathrm{~m}^{2}$ per gilt; and,

3. A service pen (Figure 1).

Oestrus detection in the gilt service pool was conducted once a day. Gilts were artificially inseminated in a service pen in the presence of a boar and transferred three to five days after second service to sow stalls in the dry sow house until day 110 of pregnancy. They were offered dry sow ration following the same feeding regime as pregnant sows (Table 4).

The farrowing rate was low for two consecutive years and

Table 4: Dry sow feed curve

\begin{tabular}{|c|c|c|}
\hline & \multicolumn{2}{|l|}{ Feed level } \\
\hline Day post weaning & $\mathrm{Kg} /$ day & MJ DE /day \\
\hline 1 & 3.4 & 44.2 \\
\hline 5 & 3.0 & 39.0 \\
\hline 7 & 3.0 & 39.0 \\
\hline 35 & 2.7 & 35.1 \\
\hline 42 & 2.1 & 27.3 \\
\hline 92 & 2.4 & 31.2 \\
\hline 110 & 2.1 & 27.2 \\
\hline
\end{tabular}

Water to meal ratio= 6.5:1; Energy: $13 \mathrm{MJ}$ DE per $\mathrm{Kg}$ of feed sow mortality rate was high. The manager contacted the author's practice requesting a veterinary investigation

\section{INVESTIGATION}

The main areas of investigation are outlined below:

- Analysis of farm records

- Past laboratory reports

- Clinical examinations

- Sample collection

- Examination of urogenital organs

\section{ANALYSIS OF FARM RECORDS}

The farm records were examined in January 2004.

Table 5: Analysis of reproductive failures (January 2001- December 2003)

\begin{tabular}{|c|c|c|c|c|}
\hline & Jan- Dec 01 & Jan-Dec 02 & Jan- Dec 03 & Target \\
\hline Farrowing rate \% & 86.0 & 77.6 & 76.3 & 89 \\
\hline $\begin{array}{l}\text { Regular returns \% } \\
18-24 \text { / } 39-45 \text { days }\end{array}$ & $n / a$ & 6.6 & 8.0 & 5 \\
\hline $\begin{array}{l}\text { Irregular returns \% } \\
\text { 23-38 days }\end{array}$ & $n / a$ & 7.0 & 5.2 & 2 \\
\hline Total returns \% & 8.0 & 13.6 & 13.2 & 7 \\
\hline $\begin{array}{l}\text { Sows not in pig \% } \\
\text { NIP (>45 days) }\end{array}$ & $n / a$ & 5.6 & 5.5 & 1 \\
\hline Abortions \% & 0.8 & 1.1 & 1.5 & $<1$ \\
\hline Culled pregnant \% & 3.7 & 0.6 & 1.6 & $<1$ \\
\hline Dead pregnant \% & 2.1 & 1.5 & 1.7 & 1 \\
\hline Pigs sold per sow per year & 22.5 & 22.0 & 20.5 & 23 \\
\hline
\end{tabular}

$1 \quad$ Alexander and Muirhead (1997) 
Table 6: Farrowing rate (FR) analysis by parity, 2003

\begin{tabular}{|l|l|l|l|l|l|l|l|l|l|l|l|} 
& Sows \& gilts & Sows only & Gilts only & Parity l & Parity 2 & Parity 3 & Parity 4 & Parity 5 & Parity 6 & Parity 7 & $>7$ \\
\hline FR \% & 76 & 78 & 66 & 68 & 80 & 77 & 79 & 77 & 82 & 82 & 85 \\
\hline
\end{tabular}

Table 7: Farrowing rate analysis in sows compared with gilts, 2003

\begin{tabular}{|l|l|l|l|}
\hline & Sows \& gilts & Sows only & Gilts only \\
\hline Farrowing rate \% & 76.3 & 78 & 66 \\
\hline $\begin{array}{l}\text { Regular repeats \% } \\
\text { 18-24 days }\end{array}$ & 5.6 & 5 & 8.9 \\
\hline $\begin{array}{l}\text { Regular repeats \% } \\
\text { 39-45 days }\end{array}$ & 2.4 & 2 & 4.8 \\
\hline $\begin{array}{l}\text { Irreg. repeats \% } \\
\text { 25-38 days }\end{array}$ & 5.2 & 5 & 6 \\
\hline $\begin{array}{l}\text { Found empty \% } \\
\text { NIP (>45 days) }\end{array}$ & 5.5 & 5 & 8 \\
\hline \begin{tabular}{l} 
Abortions \% \\
\hline Sold in pig \%
\end{tabular} & 1.5 & 1.5 & 1.6 \\
\hline Dead pregnant \% & 1.7 & 1.4 & 2.8 \\
\hline
\end{tabular}

\section{Reproductive performance}

The farrowing rate fell from $86 \%$ in 2001 to $77 \%$ in 2002 2003. The reproductive losses were mainly due to repeat breeders and sows found to be non-pregnant (Table 5).

Farrowing rates were low for all parities in 2003. Gilts had an exceptionally low rate of $66 \%$. Sows of parity over six had a farrowing rate of $83 \%$ (Table 6 ).

The reproductive losses in sows and gilts for 2003 were compared (Table 7). Repeats, found not-in-pig and sold in-pig rates were high in sows and especially in gilts.

\section{Parity profile}

The herd parity profile was high. In January 2004, the average parity, excluding unserved gilts, was five. Aherne (2002) suggested an optimal average herd parity of between 2.5-3.0.

Although the replacement rate was adequate at $40.5 \%$, the low farrowing rate in gilts resulted in insufficient gilt farrowings (Table 8). Consequently, the culling rate was reduced and old sows (parity over six) were retained. The parity distribution of the herd was examined (Table 9) and compared with the ideal parity distribution suggested by Finn (2002). The percentage of young animals (less than parity three) was satisfactory in the period October 01 to February 02, but became too low from July 2002.

Sow mortality was high, averaging $7.6 \%$ for $2001,10.7 \%$ in 2002 and $14 \%$ in 2003. Muirhead (1976) suggested a target of $3-5 \%$.

Table 8: Analysis of sow removals, 2003 (Total breeding herd of 620 sows)

\begin{tabular}{|l|l|l|l|}
\hline & No. of animals & $\%$ & \multicolumn{1}{c|}{ TARGET 1 \% } \\
\hline Sow mortality rate & 84 & 14 & $3-5$ \\
\hline Sow culling rate & 160 & 26.4 & $35-36$ \\
\hline $\begin{array}{l}\text { Removal rate } \\
\text { (mortality + culling) }\end{array}$ & 244 & 40.4 & $39-40$ \\
\hline Replacement rate & 247 & 40.5 & $39-40$
\end{tabular}

1 Muirhead (1976)

Table 9: Parity distribution analysis

\begin{tabular}{|l|l|l|l|l|l|}
\hline \multicolumn{7}{|l|}{} & \% Litters \\
\hline Parity & $\begin{array}{l}\text { \% litters } \\
\text { Target }\end{array}$ & $\begin{array}{l}\text { Oct 01- } \\
\text { Feb 02 }\end{array}$ & $\begin{array}{l}\text { July 02- } \\
\text { Nov 02 }\end{array}$ & $\begin{array}{l}\text { Dec 02- } \\
\text { May 03 }\end{array}$ & $\begin{array}{l}\text { Jun 03- } \\
\text { Dec 03 }\end{array}$ \\
\hline 1 & 20 & 18.9 & 12.0 & 12.5 & 12.1 \\
\hline 2 & 18 & 23.3 & 10.4 & 10.5 & 9.7 \\
\hline 3 & 17 & 21.8 & 18.1 & 10.1 & 9.2 \\
\hline 4 & 16 & 12.2 & 21.5 & 15.1 & 11.6 \\
\hline 5 & 14 & 7.8 & 16.3 & 19.3 & 16.6 \\
\hline 6 & 10 & 7.6 & 8.7 & 13.8 & 16.7 \\
\hline 7 & 4 & 3.0 & 7.8 & 7.2 & 10.6 \\
\hline 8 & 1 & 3.1 & 3.7 & 5.8 & 6.5 \\
\hline$>8$ & 0 & 2.4 & 1.6 & 5.6 & 7.0 \\
\hline $\begin{array}{l}\text { Whole herd } \\
\text { GILT P00L }\end{array}$ & 100 & 100 & 100 & 100 & 100 \\
$\begin{array}{l}\text { (gilts available for service } \\
\text { per 100 sows) }\end{array}$ & 4.8 & 4.8 & 4.8 & 7 \\
\hline
\end{tabular}

1 Suggested target by Carroll (1999)

\section{Sow feed consumption}

The average daily feed intake (ADFI) per sow during lactation was $5.5 \mathrm{~kg}$ in 2003. This was lower than the target of $6.2 \mathrm{~kg}$ suggested by Carroll (2005).

\section{PAST LABORATORY REPORTS}

Blood samples were collected from 20 sows in March 2003. Seram samples were analysed for evidence of porcine reproductive and respiratory syndrome (PRRS), and infection caused by Leptospira australis, Leptospira bratislava and Leptospira muenchen. The results were negative in all cases with the exception of low titres $(1 / 100)$ in three sows to Leptospira muenche, which were not considered significant.

\section{CLINICAL EXAMINATIONS}

A farm visit was carried out on January 20, 2004. The following areas were assessed:

\section{Service routine}

Sows were served in the presence of a boar, allowing nose-to-nose contact between the sows and the boar during service. Service technique was found to besatisfactory.

\section{Gilt services management}

Oestrus detection was conducted using the back-pressure test in the absence of a boar. Gilts in oestrus were served immediately in a boar pen and again 24 hours later. They were brought back after service to the pen where detection occurred and moved to sow stalls three to five days after second service.

\section{Vaginal discharges}

One sow was found with mucopurulent vaginal discharge 11 days post-service. Discharges are considered to be abnormal after seven days post-service (Muirhead 1986). Abnormal vaginal discharge, mastitis or agalactia was not observed in lactating sows. 


\section{Sow stalls}

Six stalls in the main dry sow house were damaged (Figure 2), allowing some sows to escape and injure other sows by mounting them.

\section{Service area hygiene}

Washing and disinfection was not being carried out. A build-up of faeces was evident behind some sows (Figure 2).

\section{Dry sow house lighting}

Fluorescent lights were switched on for six hours a day. Light intensity at sow level was 200 lux in different areas of the house.

\section{Boar exposure}

Only one boar was present in the gilt pool area. In the dry sow houses boar contact was not maintained after service.

\section{Sow body condition}

Body condition was scored at weaning, using a visual condition scoring system based on a 10-point scale described by Whittemore (1998). Condition score two is thin and boney, while eight is evident fat. A minimum condition score of around fouris the target at weaning and sows should farrow with a minimum condition score of about six. Scores above seven and below three are unacceptable at any time. Sow condition was variable. Between $20-25 \%$ of the weaned sows had a condition score four or less, and $75-80 \%$ had a score of five.

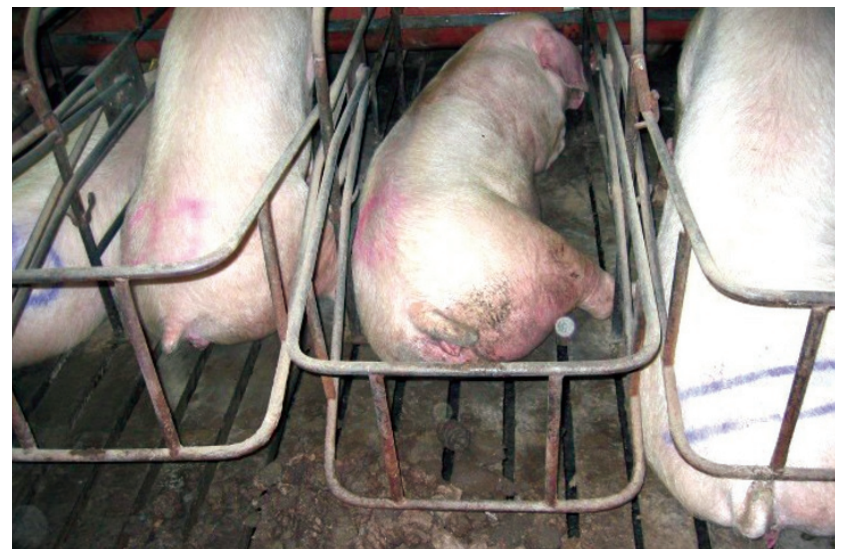

Figure 2: Build-up of faeces behind the sow and damaged stalls in the dry sow house.

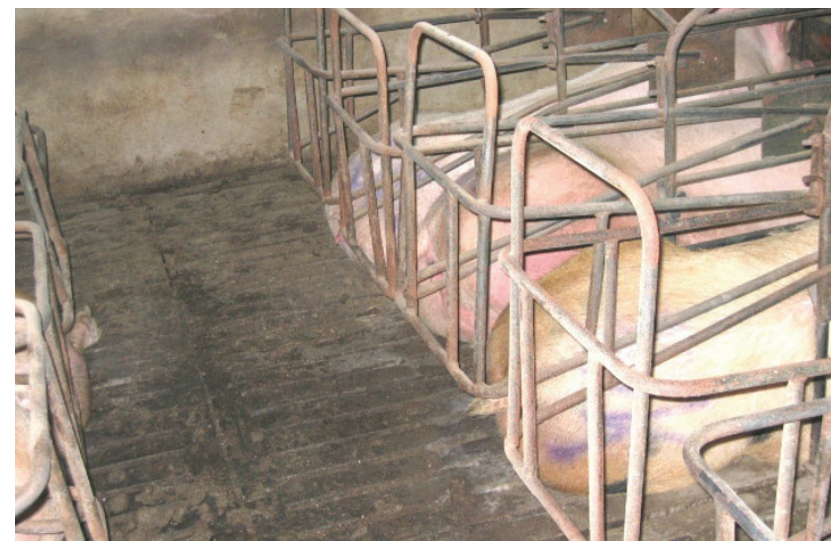

Figure 3: Rear view of the sow stalls showing design modification.

\section{Lactating sow feeding and water supply}

Some feed troughs appeared very clean suggesting underfeeding. Water was supplied via a computerised liquid feed system in the morning and evening time; water nipples were not present in the troughs.

\section{Sow mortality}

No dead sows were available for necropsy during the investigation period. A number of culled sows were condemned due to emaciation. On-farm sow euthanasia level was high due to injuries, lameness or poor general health.

\section{SAMPLE COLLECTION}

The following samples were collected as part of the laboratory investigation:

\section{Water samples}

Drinking water samples were collected and submitted for analysis. Coliform organisms were detected, but numbers were lower than acceptable limits for livestock (less than 5,000 total coliforms $/ 100 \mathrm{ml}$ and less than 1,000 faecal coliforms / $100 \mathrm{ml}$ ) suggested by the US Environmental Protection Agency (1973).

\section{Blood samples}

Blood samples were collected from 20 sows and subjected to serological assays for PRRS, Aujeszky's disease (AD), Swine Influenza (SI) and Leptospira spp were carried out. PRRS and AD results were negative. Swine influenza H1N1 and H3N2 titres were negative or less than or equal to $1 / 80$ in some sows, which was not considered significant. No titres for Leptospira australis titres were detected. Leptospira bratislava and Leptospira muenchen titres were negative except for a titre of $1 / 100$ which was not considered to be significant.

\section{EXAMINATION OF UROGENITAL ORGANS}

Ten sows were culled on January 29, 2004 as a result of poor reproductive performance and their urogenital tracts were

examined. The findings of the examination are outlined in Table 10.

Table 10: Summary of findings/ results of examination of urogenital organs on January 29, 2004

\begin{tabular}{l|l|ll} 
Sow number & Uterus & Bladder & \\
& Gross findings / result & Cystitis & Comment / results \\
\hline N/A & Normal & Yes & - \\
\hline 1580 & Normal & Yes & - \\
\hline N/A & Normal & No & - \\
\hline N/A & Normal & No & - \\
\hline 2204 & Pus / E. coli & Yes & Pus / E. coli \\
\hline N/A & Normal & No & - \\
\hline 1799 & Normal & Yes & Haemorrhage \\
\hline 1364 & Normal & Yes & - \\
\hline N/A & Normal & No & - \\
\hline N/A & Normal & No & - \\
\hline
\end{tabular}

$1 \quad$ N/A: Not Available 


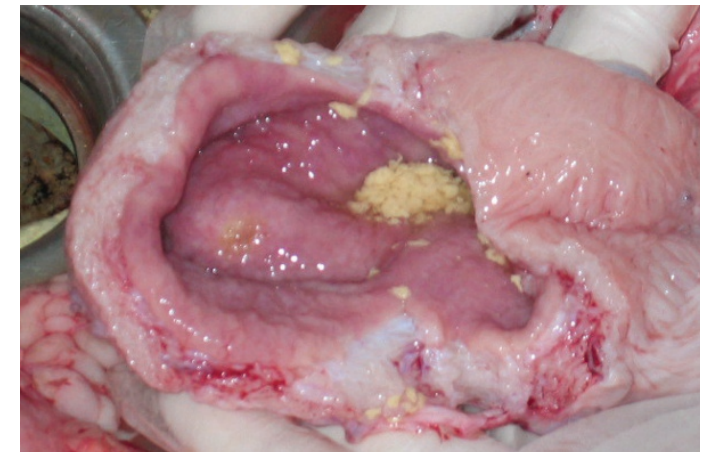

Figure 4:

Cystitis in a

bladder of a

culled sow.

Fifty per cent of the bladders examined had evidence of cystitis (Figures 4). Kidneys were not examined.

Swabs were collected from gross lesions in the uterus, cervix and bladders and two urine samples were collected for bacteriology. Oviducts from four sows were collected and subjected to a fluorescent antibody test (FAT) for Leptospira bratislava with negative results. Escherichia coli was isolated from the bladder, the cervix and urine sample of sow number 2204.

On February 13, 2004 nine infertile sows were culled. The urogenital organs, including kidneys were examined. Gross changes were similar to previous ones (Table 11). Seventyeight per cent of bladders examined had thickened walls and hyperaemia of the mucosa. All kidneys were normal and E. coli was isolated from the bladder of sow 1596.

\section{DIFERENTIAL DIAGNOSIS}

1. PRRS was excluded on the basis of negative serological results;

2. Aujeszky's disease was excluded on the basis of negative serological results;

3. Swine influenza H1N1 and H3N2 was excluded on the basis of absence of clinical signs and insignificant serological titres (lower or equal to $1 / 80$ );

4. Porcine parvovirus was excluded on the basis of an effective vaccination programme and absence of an increase in mummifications which remained below $0.5 \%$ of pigs born. Muirhead (1986) specified less than $0.5 \%$ as a target level for mummifications;

5. Leptospira infections were excluded on the basis of negative serology results and negative FAT results on fallopian tube samples;

Table 11: Summary of findings / results of examination of urogenital organs on February 13, 2004

\begin{tabular}{|l|l|l|l|l|}
$\begin{array}{l}\text { Sow } \\
\text { number }\end{array}$ & Uterus & Bladder & Kidney \\
\hline 1201 & Gross findings / results & Cystitis & $\begin{array}{l}\text { Comment / } \\
\text { results }\end{array}$ & comment \\
\hline 1402 & Normal / - & No & - & Normal \\
\hline 1448 & Normal / - & Yes & - & Normal \\
\hline 2111 & Normal / - & Yes & Hyperaemic & Normal \\
\hline 1596 & Normal / - & Yes & - / E. coli & Normal \\
\hline 1990 & Normal / - & Yes & - & Normal \\
\hline 2023 & Normal / - & Yes & - & Normal \\
\hline 1546 & Normal / - & Yes & - & Normal \\
\hline 2078 & Normal / - & No & - & Normal \\
\hline
\end{tabular}

6. Cystitis;

7. Poor gilt management routine, including inadequate oestrus detection, overfeeding regime post-service and stress associated with possible mounting of served gilts still on heat by pen mates; and,

8. Inadequate culling policy.

\section{DIAGNOSIS}

Following examination of farm records, clinical, urogenital examinations and laboratory investigations, the main contributory factors to the problem were:

- Infectious:

Cystitis, associated with $\boldsymbol{E}$. coli infection.

- Non-infectious:

Sub-optimal oestrus detection frequency;

Sub-optimal gilt oestrus detection technique;

Overfeeding during the immediate post service period; and, Inadequate culling policy leading to an aged breeding herd.

\section{RECOMMENDED CONTROL PROGRAMME: RECORDING OF ABORNMAL POST-SERVICES DISCHARGES}

The farm manager was instructed to record the following details for each sow:

- Sow identification and parity;

- Number of days post-service; and,

- $\quad$ Subsequent reproductive performance. The farmer was also instructed to collect vaginal swabs in a sterile manner. A demonstration of the correct technique to avoid contamination was provided.

\section{Recording of presumptive cause of sow death}

This was introduced in January 2004 and was determined by the clinical assessment of the carcase, within the limitations, by the farm manager or submission when possible to the laboratory.

\section{Oestrus detection - service programme}

It was recommended that oestrus detection be carried out twice a day for gilts and sows in the presence of a mature boar. Services were to be carried out when standing oestrus was first detected and repeated 24 hours later. This recommendation wasnot implemented.

\section{Management of gilt services}

Gilts were to be moved from the gilt pool accommodation to gilt pens in the sow service area at the first recorded oestrus and then served in stalls on the second recorded oestrus. This recommendation was not implemented.

\section{Target gilt services per week}

In January 2004, it was advised to increase gilt services to 10 services per week, to compensate for low farrowing rates and to allow for an increased culling rate of old sows. 


\section{Hygiene programme in the service area}

Removal of faeces from behind the sows and power washing and disinfection between batches was recommended for the prevention of ascending urogenital infections. The recommendations were not implemented.

\section{Modification of sow stalls}

The rear of the stalls in the dry sow house was modified in April 2004 to ensure that all sows were confined in stalls Figure 3).

\section{Boar exposure}

It was recommended that boar contact in the dry sow houses and gilt pool area be increased. This measure was disregarded.

\section{Pregnancy testing frequency}

Pregnancy testing was conducted twice, at 28 days postservice and repeated at 42-50 days.

\section{Gilt nutrition}

A revised feeding programme was recommended (Table 12).

Table 12: Gilt feeding programme

\begin{tabular}{|l|l|l|l|l|}
\hline $\begin{array}{l}\text { Bodyweight } \\
(\mathrm{Kg})\end{array}$ & Event & Diet & $\begin{array}{l}\text { Feed density } \\
\text { (MJ DE } / \mathrm{Kg})\end{array}$ & $\begin{array}{l}\text { Feed Level } \\
\text { (Kg/day) }\end{array}$ \\
\hline $95-120$ & Selection & Gilt & 13 & 2.5 \\
\hline $121-135$ & $\begin{array}{l}\text { Transfer into sow } \\
\text { service area until } \\
\text { service }\end{array}$ & Lactating sow & 15 & Ad libitum \\
\hline$>135 \mathrm{~kg}$ & $\begin{array}{l}\text { 2nd service to } \\
\text { farrowing }\end{array}$ & Dry sow & 13 & 2 \\
\hline
\end{tabular}

\section{Nutrition during lactation}

Feed levels were adjusted daily according to individual sow condition and appetite.

\section{Light intensity in service area}

Light intensity was increased to 250 lux at sow level. A timer was installed to ensure exposure to 14 hours light per day.

\section{Culling policy}

A guideline to the recommendations made is outlined below:

- Weaned sows with shoulder sores, ulcerated hocks or traumatic injuries;

- Sows with abnormal vulva discharge; and,

- $\quad$ Old sows (parity over seven).

\section{Water supplied to pregnant sows}

An extra six litres of water per day, between the morning and the evening feeding times was provided to each pregnant sow using a computerised liquid feed system. The extra water supplied was generally consumed.

\section{Dietary urinary acidifier}

Ammonium chloride (97\%) was included in the dry sow ration at a rate of $6 \mathrm{~kg}$ per tonne and in the lactating sow ration at a rate of $2.5 \mathrm{~kg}$ per tonne for eight consecutive weeks, commencing in late January 2004.

\section{SUBSEQUENT CASE OUTCOME I}

1. The farrowing rate remained low: $76 \%$ in $2003 ; 77 \%$ in 2004. The analysis of the reproductive performance between June and December 2004 is outlined in Tables 13-14. The repeat, not-in-pig and culled pregnant sow rates were high.

2. The average daily feed intake per lactating sow increased from $5.5 \mathrm{~kg}$ during 2003 to $6.8 \mathrm{~kg}$ for the period March-September 2004.

3. The age profile of the herd remained high. A sow parity distribution analysis conducted in September 2004 showed that $23 \%$ of the sows in the herd were over parity six compared with $26 \%$ in 2003.

Table 13: Analysis of farrowing rates by parity (June-December, 2004)

\begin{tabular}{|l|llllllllllll}
$\%$ & Sows \& gilts & Sows only & Gills only & Parity 1 & Parity 2 & Parity 3 & Parity 4 & Parity 5 & Parity 6 & Parity 7 & $>7$ \\
\hline FR & 78 & 82 & 65 & 78 & 89 & 86 & 79 & 82 & 83 & 83 & 82
\end{tabular}

FR: Farrowing rate

Table 14: Analysis of reproductive failures (2004)

\begin{tabular}{|c|c|c|c|c|c|c|c|c|}
\hline$\%$ & Jun 04 & Jul 04 & Aug 04 & Sept 04 & Oct 04 & Nov 04 & Dec 04 & Jan -Dec 04 \\
\hline Farrowing rate & 77 & 83 & 82 & 70 & 78 & 76 & 78 & 77 \\
\hline Regular returns 18-22 /39-45 days & 5.1 & 6.9 & 4.9 & 9.1 & 8 & 6.2 & 8.2 & 7.3 \\
\hline Irregular returns 23-38 days & 4.3 & 3.7 & 4.1 & 7 & 1.3 & 4.9 & 1.7 & 4.2 \\
\hline Sows not in pig $>45$ days & 11 & 3.1 & 6 & 7 & 1.3 & 4.9 & 3.5 & 5.7 \\
\hline Abortions & 0 & $<1$ & $<1$ & 2 & $<1$ & $<1$ & 1.7 & 1.1 \\
\hline Culled pregnant & $<1$ & 1.2 & 2 & 5.6 & 5.4 & 3.5 & 5.3 & 2.5 \\
\hline Dead pregnant & 1.4 & 1.2 & 0 & $<1$ & 2 & $<1$ & 1 & 1.8 \\
\hline
\end{tabular}


4. The number of maiden gilts in the pool increased from 33 in January 2004 to 99 in September 2004. An average of seven gilts were served per week from January-October 2004.

5. The level of abnormal post-service vaginal discharges recorded from January-June 2004 was 1.7\% (Table 15). The type of discharge observed was creamy without blood in sows between seven to 50 days after service. The duration of the discharge varied from one to five days.

6. Vaginal swabs were collected from four sows that had abnormal post-service discharge and sent to the laboratory for bacteriological examination. The results are summarised on Table 16.

Table 15: Observations of vulva discharges from January 04-30 June 04 (Farrowed between May 04-0ctober 04)

\begin{tabular}{|l|l|l|} 
& Number of sows & $\%$ \\
\hline Served & 874 & - \\
\hline Farrowed & 600 & 68.6 \\
\hline Discharge & 15 & 1.7 \\
\hline
\end{tabular}

Table 16: Bacteriology results - vaginal swabs, February-April 2004

\begin{tabular}{|l|l|l|l|l|l|}
\hline Sow ID & Parity & E. coli & Streptococcus & Staphylococcus & Salmonella \\
\hline 1581 & 7 & + & + & + & - \\
\hline 1394 & 8 & + & - & - & - \\
\hline 1479 & 7 & + & + & + & - \\
\hline 2355 & Gilt & + & - & + & - \\
\hline
\end{tabular}

+: Isolated. -: not isolated

Table 17: Presumptive diagnosis of cause of sow death and number of sows recorded by the farm manager from January-August 2004

\begin{tabular}{|l|l|l|l|l|l|l|l|l|}
\hline CAUSE & $\begin{array}{l}\text { Jan } \\
\text { O4 }\end{array}$ & Feb 04 & Mar 04 & Apr 04 & $\begin{array}{l}\text { May } \\
04\end{array}$ & $\begin{array}{l}\text { Jun } \\
04\end{array}$ & Jul 04 & $\begin{array}{l}\text { Aug } \\
04\end{array}$ \\
\hline Unknown & 0 & 0 & 2 & 1 & 1 & 0 & 0 & 2 \\
\hline Infection & 0 & 2 & 4 & 1 & 1 & 3 & 1 & 1 \\
\hline Accident & 0 & 2 & 3 & 1 & 1 & 1 & 0 & 1 \\
\hline Bullied & 1 & 3 & 1 & 2 & 2 & 1 & 0 & 0 \\
\hline Total & 1 & 7 & 10 & 5 & 5 & 5 & 1 & 4
\end{tabular}

Table 18: Summary of findings/results of examination of urogenital organs on October 20, 2004

\begin{tabular}{|c|c|c|c|c|}
\hline & Uterus & Bladder & & Kidney \\
\hline Sow number & Findings / results & Cystitis & Comment & Gross findings \\
\hline 2416 & Normal / - & Yes & Mild & Normal \\
\hline 2195 & $\begin{array}{l}\text { Abnormal } \\
\text { Congestive mucosa }\end{array}$ & Yes & Mild & Normal \\
\hline 1328 & $\begin{array}{l}\text { Abnormal } \\
\text { Congestive mucosa. } \\
\text { Small amount of pus } \\
\text { present in the lumen }\end{array}$ & Yes & Mild & Normal \\
\hline 2450 & $\begin{array}{l}\text { Abnormal } \\
\text { Congestive mucosa }\end{array}$ & Yes & Mild & Normal \\
\hline 1795 & Normal / E. coli & Yes & Severe & Normal \\
\hline 2206 & Normal / - & Yes & Mild & Normal \\
\hline 2452 & Normal / - & No & - & Normal \\
\hline 2061 & Normal / - & No & - & Normal \\
\hline 1628 & Normal / - & No & - & Normal \\
\hline 2448 & Normal / - & No & - & Normal \\
\hline
\end{tabular}

7. Sow mortality reduced from $12.9 \%$ (October-December 2003) to $7.8 \%$ (July-September 2004). One sow was submitted to the laboratory for necropsy. A splenic torsion was reported. A list of presumptive causes of sow death recorded by the farm manager is outlined in Table 17.

8. Examination of urogenital organs from infertile gilts and sows (parity range 27) on October 20, 2004 revealed

that incidence of cystitis had not fallen (Table 18).

Samples for bacteriological analysis were collected from the uterus, bladder and kidney where gross changes were observed and a urine sample was collected. Culture techniques were conducted on the material collected. $E$. coli was isolated from uterus and bladder of sow 1795.

Eight blood samples were collected and seriological examination for Leptospira spp. was negative.

9. Subsequent case outcomes also resulted in staff changes. Due to an incomplete implementation of recommendations, the unit manager, who started working in the unit in September 2001, was laid off and a new manager was appointed in January 2005.

\section{SUBSEQUENT CASE OUTCOME II}

In a meeting with the new unit manager in January 2005 the previous recommendations were reviewed. Emphasis was made on the following points:

- Implementation of an active culling policy;

- Introduction of twice-a-day oestrus detection policy in the presence of a boar;

- Implementation of gilt services in stalls in the sow service area;

- Upgrading service area hygiene; and,

- Frequent exposure between served sows/gilts and boars.

After the full implementation of recommendations significant improvements were observed:

1. The farrowing rate increased from $78 \%$ (January-March 2005 ) to $85 \%$ for sows and gilts, and to $84 \%$ for gilts only for the period April-October 2005; and,

2. Sow mortality rate reduced to $4.1 \%$ (April-October 2005).

\section{DISCUSSION}

The impaired fertility problem affected mainly gilts and first parity sows; however, older sows had a higher farrowing rate. Therefore the high parity profile may in the short term have been beneficial to the fertility of the herd.

It is normally stated that oestrus period in the sow lasts 24-60 hours and ovulation occurs 38-42 hours after the onset of heat. Service should take place up to 12 hours before ovulation. A delay in mating could result in lowered embryo survival (Muirhead 1991). Oestrus detection occurred every 24 hours. Therefore, some gilts or sows may have been on the point of ovulation when first detected resulting in conception failure. White (2006) suggested checking for signs of oestrus at least every 12 hours. 
Gilts that have been moved into a boar pen for service and returned to a group pen can experience increased stress levels sufficient to cause pregnancy failure (White 1996). In the present case study gilts were returned immediately after service to group pens for a period of three to five days. This may have triggered adrenaline secretion due to excessive mating behaviour of gilts in oestrus by pen mates during the immediate post- service period. White (1996) stated that sperm transport to the uterotubal junction and then to the fallopian tube is influenced by oxytocin release and that adrenaline is an antagonist to oxytocin.

Boar exposure to served gilts and sows in the unit was restricted. In this context, it is notable that White (1996) reported that the presence of a boar has a beneficial effect on the maintenance of pregnancy, and secondly that boar contact further helps to stimulate oestrus and its detection 18 to 23 days after service if conception has failed to occur.

Suboptimal light intensity (200 lux) was observed in the main dry sow house. Lighting periods were insufficient (six hours per day). Alexander and Muirhead (1997) recommended a minimum of 220 lux during the dry period for 14 hours a day to maintain a viable pregnancy. Young (2003) stated that high level feeding during the first few days of pregnancy is likely to increase hepatic blood flow and clearance of progesterone resulting in a depressed concentration of progesterone in the blood that may affect embryo survival during early pregnancy. The feed level offered to the gilts and sows in the immediate post-service period was high and may have caused conception failure.

Almond (1995) stated that attempts to breed sows with signs of abnormal vulva discharge are usually futile. This is in agreement with this case study in which seven out of 15 discharging sows repeated.

The recommended water requirement for pregnant sows is between 8-12 litres per day (Henry and Apley 1999). Although adequate volumes of water were supplied to pregnant sows, (approximately 13-19 litres per sow per day), the extra water meant to encourage water consumption, thus reducing periods of recumbency and the intervals between urination episodes. This may have a positive flushing effect on the bacteria in the bladder to increase as coliform bacteria replicate every 40 minutes (Carr et al. 1995) and cystitis develops when the bladder is not emptied frequently and bacteria concentrate in the urine increasing the risk of infection of the bladder. Deen and Xue (1999) found that where the gilt pool was too small, sow deaths increased due to sows being retained too long in the absence of a suitable replacement. In this case study, the number of gilts available for service was sub-optimal and, as a result, old sows were retained increasing sow deaths and pregnancy losses due to on-farm euthanasia and casualty slaughter. Carroll (1999) stated that a sound culling policy is an integral part of herd management as old sows retained in herds lead to decreased productivity.
A significant reduction in sow mortality subsequent to staff change was observed. This was due to a high culling rate $(68 \%)$ during the first quarter of 2005.

Jones (1968) reported that urinary tract disease was one of the main causes of death in sows kept under intensive conditions. In the present study, the sow death rate was over 9\% throughout the period of investigation. Carr, Walton and Done (1995) stated that if annual sow deaths were in excess of $5 \%$, then cystitis and pyelonephritis must be considered possible causes. The presence of cystitis in a high proportion of old sows may have predisposed to increased sow mortality.

Thornton et al. (1998) studied two herds where subclinical urogenital infection (UGI) was present and where discharge rates remained below $2 \%$. They reported that older sows have higher rates of $U \mathrm{GI}$ and that subclinical UGI during gestation possibly contributes to a reduction of farrowing rate because of early embryonic deaths, abortions and sow deaths. Similar findings were observed in the present study. The post-service vaginal discharge rate recorded $(1.7 \%)$ involved mainly parity five to eight sows and was associated with reproductive failure.

The use of ammonium chloride was considered to be of potential benefit as a urinary acidifier to aid in the control of cystitis. Carr et al. (1995) and Wendt (1998) stated that ammonium chloride can be useful in the prevention of urinary tract infections. The former author stated that ammonium chloride has little effect in the absence of antibiotics. However, Spillane (1998) reported a significant improvement in conception rate from the inclusion of ammonium chloride in sow feed in the absence of antibiotics. In the present case, a response to the urinary acidifier, in the absence of antibiotics was not observed. The improved performance in the unit subsequent to a staff change was an interesting feature of this case. Almond (1995) stated that detailed investigations of sow infertility problems on large farms demonstrated that the human factor continues to be a primary cause of unacceptable sow performance.

\section{CONCLUSION}

This study highlights the importance of monitoring and evaluating breeding management practices for the achievement of optimum reproductive performance in pig herds.

\section{ACKNOWLEDGEMENTS}

The author wishes to thank Michael Burke and Paul Spillane for their assistance and advice provided in writing this study.

\section{REFERENCES}

Aherne FX (2002) Improving breeding herd efficiency: An industry perspective. IN: Proceedings of the $29^{\text {th }}$ Annual Pig Health Society Symposium, The Curragh Race Course, Co Kildare, Ireland, p 30.

Almond GW (1995) Investigation into sow infertility. The Pig Journal 35, p20. 
Alexander TJL, Muirhead MR (1997) Reproduction: Non-infectious infertility. IN: Managing pig health and the treatment of disease. ( $1^{\text {st }}$ edn)Sheffield, 5M Enterprises Limited, p133.

Carr J, Walton J and Done S (1995) Cystitis and ascending pyelonephritis in the sow. In Practice 17, p 71.

Carroll C (1999) Sow culling and parity profiles. IN: Proceedings of the pig farmers' conferences Teagasc 1999, Longford, Ireland, p 35.

Carroll C (2005) Maximising lactation feed intakes. IN: Proceedings of the pig farmers ${ }^{\prime}$ conferences Teagasc 2005, Kilkenny, Ireland, p18.

Deen J, Xue J (1999) Sow mortality in the US: an industry-wide perspective. IN: Proceedings of the Allen D. Leman Swine Conference, St. Paul, Minnesota, USA, p 91.

Finn J (2002) Producing larger litters - the challenge. IN: Proceedings of the pig farmers' conferences Teagasc 2002, Cavan, Ireland, p 40.

Henry SC, Apley (1999) Therapeutics. IN: Diseases of swine $\left(8^{\text {th }}\right.$ edn) Straw BE, D`Allaire S, Mengeling et al. (eds) lowa, State University Press. p 1155.

Jones J (1968) The cause of death in sows: A one year survey of 106 herds in Essex. British Veterinary Journal 124, p 45.

Muirhead MR (1976) Veterinary problems of intensive pig husbandry. Veterinary Record 99, p 288.

Muirhead MR (1986) Epidemiology and control of vaginal discharges in the sow after service. Veterinary Record 119, $p$ 233.

Muirhead MR (1991) Reproductive failure in the sow. IN: Pig refresher course, Fertility and infertility. The University of Liverpool, UK, p 59.

Spillane P (1998) Cystitis and endometritis in a 1000 sow unit. The Pig Journal 44, p 162.

Thornton EJ, Wilson RJ, Connaughton, I et al. (1998) Effect of subclinical urogenital infection on reproductive performance in the sow. IN: Proceedings of the 15th International Pig Veterinary Society Congress, Birmingham, UK, p 236.

US Environmental Protection Agency (1973) Proposed criteria for water quality, quality of water for livestock, Environ Rep 4 (16) p 663.

Wendt M (1998) Urinary system disorders of pigs. IN: Proceedings of the 15th International Pig Veterinary Society Congress, Birmingham, p 167.

White M (1996) Reproductive physiology of the pig - theory into practice. In Practice 18, p 108.

White $M(2006)$ When is the best time to serve a sow? NADIS Pig Focus. [Online] Available from: www.nadis.org.uk. [Accessed March 2007].

Whittemore C (1998) Feeding requirements for breeding sows: complex is clever, but simple is safer. In Practice 20, p 304.

Young (2003) Nutrition and management of the modern gilt. Proceedings of the pig farmers' conferences Teagasc 2003. Kilkenny, Ireland, p 41. 